\title{
The synthesis and biological activities of 3-acyl-2,3-dihydro-1,3,4-oxadiazole / 3-acyl-1,3,4-oxadiazoline derivatives obtained from hydrazide-hydrazones
}

\author{
Sevim Rollas, Sevgi Karakuş
}

\begin{abstract}
In this review, the synthesis and biological activities of 3-acyl-2,3-dihydro-1,3,4oxadiazole derivatives are reported. Synthesis of 1,3,4-oxadiazolines via carboxylic acid hydrazide-hydrazones by using acetic anhydride or other cyclization agents establishes the peculiar basis of our work.
\end{abstract}

KEYWORDS: 2,3-dihydro-1,3,4-oxadiazole, 3-acyl-1,3,4-oxadiazoline, hydrazide hydrazones, biological activities.

\section{INTRODUCTION}

The hydrazide-hydrazones are obtained from the condensation of hydrazides and aldehyde or ketones (1-5). Also, unsubstituted or monosubstituted hydrazones are converted into hydrazide-hydrazones with acylated agents (1). Being one of the most important raw material, hydrazide-hydrazones and hydrazones have been used in the various chemical synthesis (1,6-10). The acyl- and aroylhydrazones are very important as chelating agents (11-14) Compounds containing hydrazide and hydrazone moiety proved to be especially attractive due to their application in biology $(4,15-$ 21) and medicine, isocarboxazide, iproniazide, isoniazid, nifuroxazide, rifampisin as example drugs. Also hydrazones are the most important compounds for prodrug design due to their poor metabolic stability $(1,22-24)$. The plasma stability of the prodrugs is very important for rapid conversion in plasma (25). The formation of hydrazone is an suitable reaction for prodrug synthesis (26-30). They are easily hydrolyzed to active drugs in vivo. Hydrazide-hydrazones have also been employed for the preparation of the heterocyclic compounds such as 4 -thiazolidinone $(31,32)$, azetidinone $(33,34), 1,3,4$-oxadiazole and 2,3-dihydro1,3,4-oxadiazol rings. The substituted 1,3,4-oxadiazole derivatives have been obtained from hy- drazide-hydrazones by the oxidative cyclization (35-37). The hydrazone functional group is usually not stable in vivo $(22,38)$ and in vitro $(23,39)$. However the hydrolytic stability of hydrazones are depend on the structure of the substituent (1). 2,3-Dihydro-1,3,4-oxadiazol derivatives are stable structures (40) and obtained from intramoleculer cyclization of hydrazide hydrazones by acid anhydrides or acylchlorides (1,41-46). In 1953, Yale and co-workers (41) reported the publication of related compounds. In 2002, Rollas and co-workers (45) demonstrated that some hydrazones of 4-fluorobenzoic acid hydrazide and their 1,3,4-oxadiazoline derivatives showed antibacterial and antifungal activities. The monoamine oxidase inhibitory activities of 3-acetyl-1,3,4-oxadiazolines were investigated by Maccioni and co-workers (47). The most detailed researches have been made by Somogyi and co-workers (42, 48-51).

There are only a few reports on 3-acetyl-1,3,4- oxadiazolines which obtained from hydrazide-hydrazones with acetic anhydride and the other cyclization agents. Purpose of this review is to summarize synthetic approaches and report the biological activities of 3-acyl-2,3-dihydro-1,3,4-oxadiazol derivatives. The literature covers through 1953.
AFFILIATIONS

Marmara Üniversitesi Eczacılık Fakültesi, İstanbul, Türkiye

CORRESPONDENCE

Sevim Rollas

E-mail:

sevim@sevimrollas.com

Received:

10.04.2012

Revision:

30.04.2012

Accepted:

30.04 .2012 
SYNTHESIS OF 3-ACYL-2,3-DIHYDRO-1,3,4-

OXADIAZOLE DERIVATIVES

Cyclizaton of hydrazide-hydrazones

\section{Acetyl derivatives}

The 3-acetyl-2,3-dihydro-1,3,4-oxadiazole derivatives have been obtained via acetylation and intramolecular cyclation of hydrazide-hydrazones using acetic anhydride. The 3-acetyl1,3,4-oxadiazolines 1 (41), 2 (43), 3 (44, 52), 4 (53), 5 (54), 6 (55), 7 (56), 8 (57) and 9 (58), 10 (59), 11 (60) and 12 (61) were synthesized by the cylization of the corresponding hydrazide-hydrazone derivatives in acetic anhydride. The reaction time, temperature, and yields have been shown slightly different.

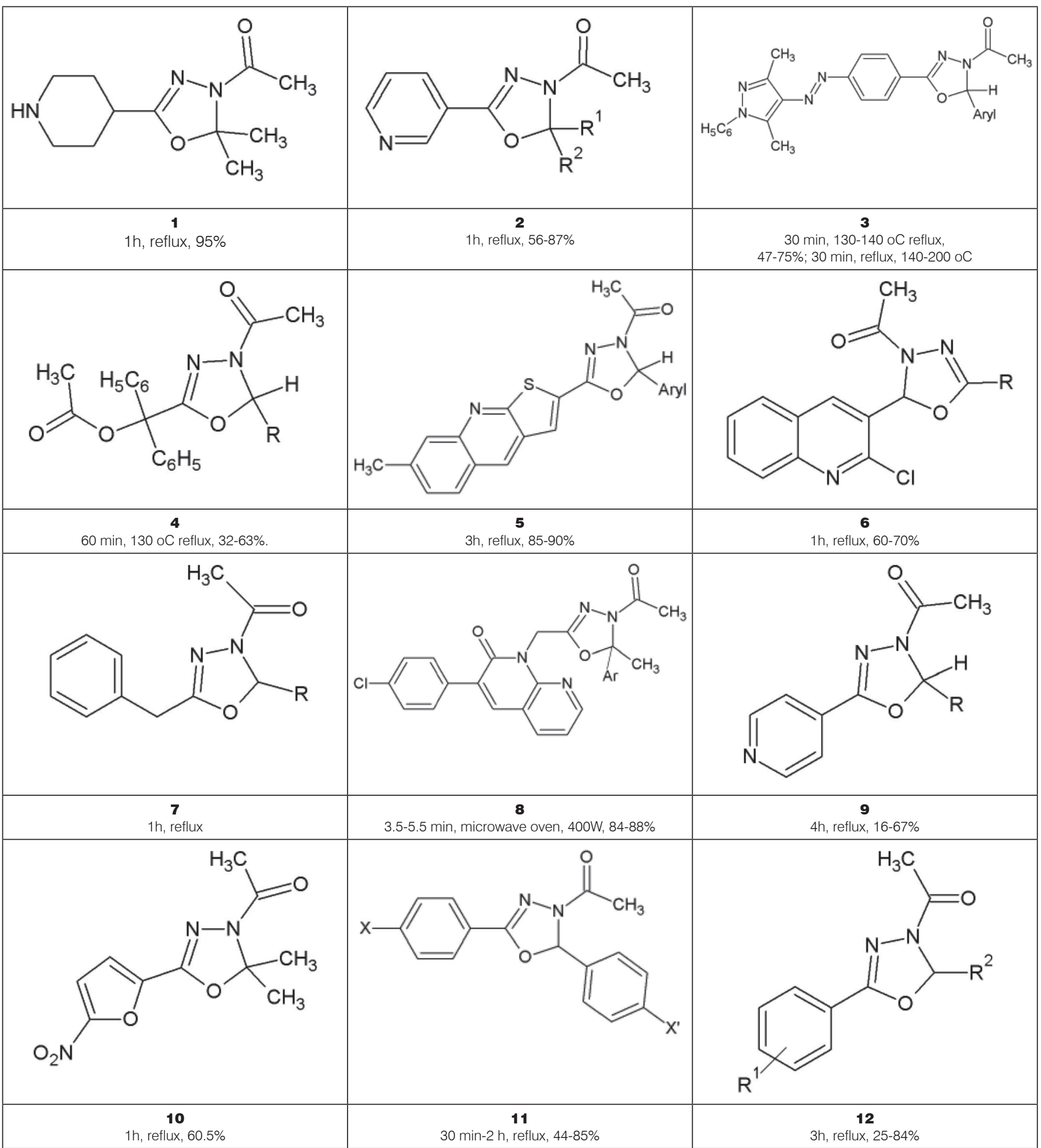




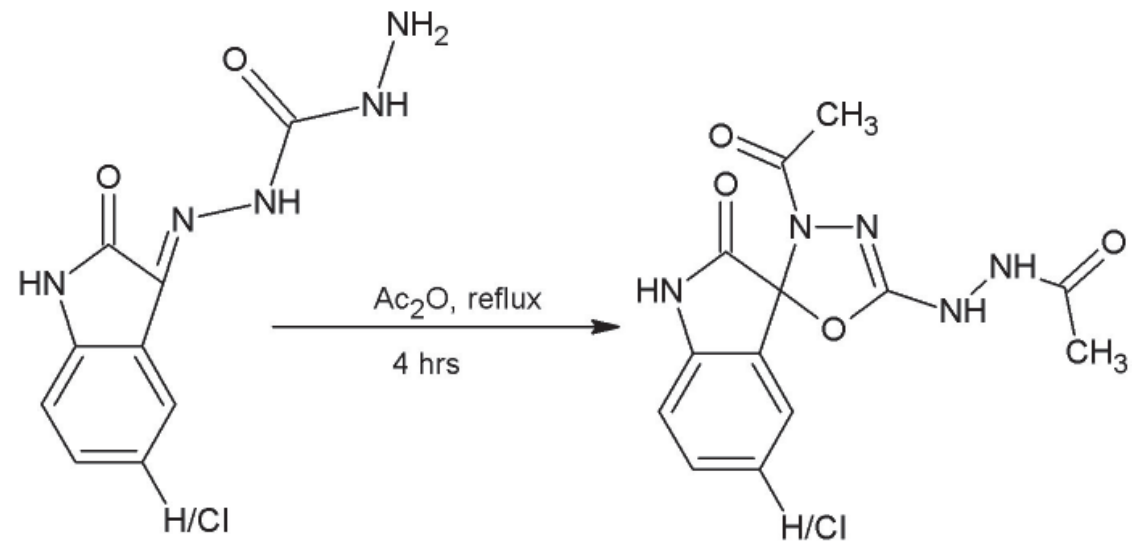

13

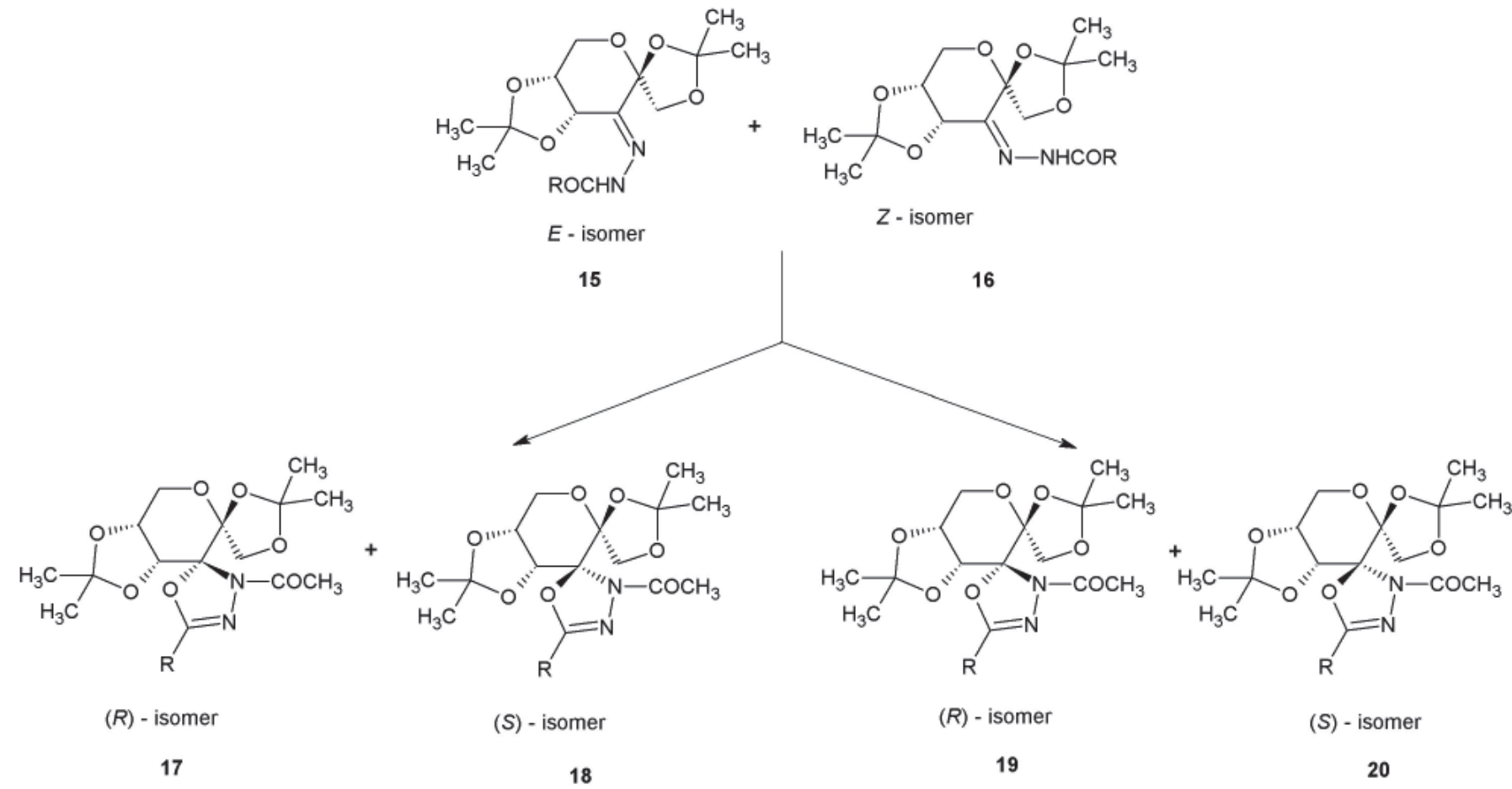

In the other variations of this method, anhydrous sodium acetate (62) has been added in the reaction medium besides acetic anhydride. Also, the 1,3,4-oxadiazolines were synthesized from the corresponding hydrazide-hydrazones in acetyl chloride $(48,63,64)$.

On the other hand, the spiro 1,3,4-oxadiazolines were obtained from the reaction acetic anhydride 14 (65) 17, 18, 19, 20 (66) or acetic acid 22 (67) on cyclic ketone-hydrazone derivatives.

The compounds were obtained with (R)- and (S)- configurations at C-3 (66). Wang and co-workers (67) isolated also the E and $\mathrm{Z}$ isomer of some hydrazide hydrazones and from these isomers synthesized the $S$ and $\mathrm{R}$ isomers of spiro1,3,4-oxadiazoline derivatives.

The cyclization of $\mathbf{2 1}$ was carried out in acetic acid by Allam and co-workers (68) and obtained nonacetylated spiro1,3,4oxadiazoline derivative 22 .<smiles>CC(=O)CC(=O)N/N=C1\C(=O)Nc2ccccc21</smiles>

21<smiles>N#CC1=NNC2(O1)C(=O)Nc1ccccc12</smiles>

22 
The dehydrogenation of 3-acetyl-2,3-dihydro-1,3,4-oxadiazoles 24 with potassium permanganate has been given substituted 1,3,4-oxadiazoles 25 (51)

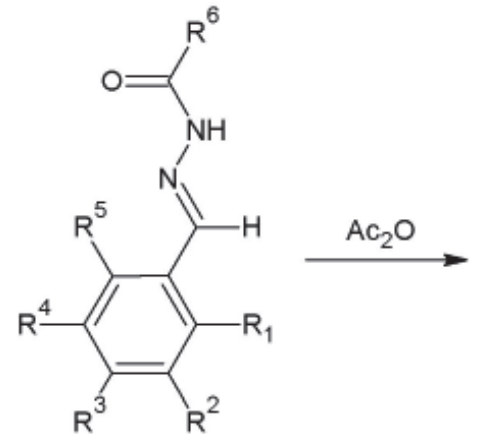

23<smiles>[R]C1=NN(C(C)=O)C(c2c([R])c([R])c([R])c([R])c2[R])O1</smiles>

24<smiles>[R]c1nnc(-c2c([R])c([R])c([R])c([R])c2[R])o1</smiles>

25

Similarly, the 3-acetyl-2,3-dihydro-1,3,4-thiadiazole derivatives 27 (69) are obtained from thiosemicarbazones. When the cylic ketone is used, the spiro 1,3,4-thiadiazolines 29 have been formed (70).

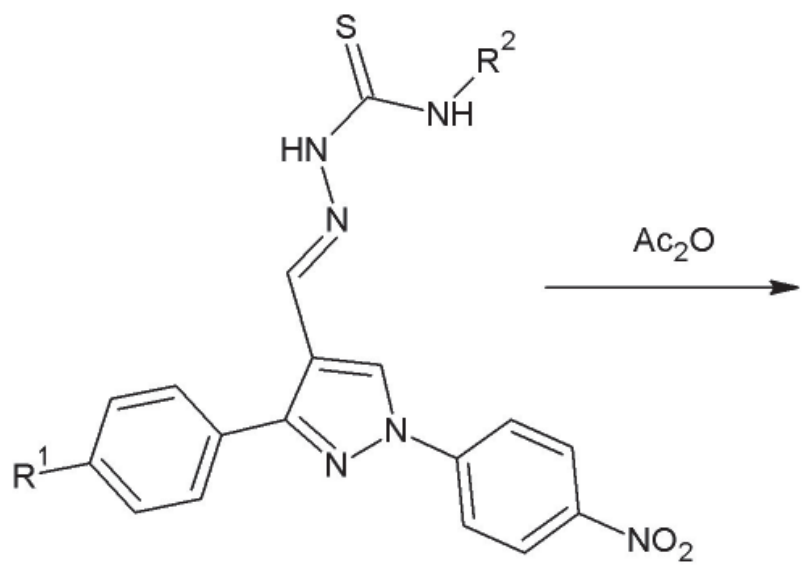

26<smiles>NC(=O)NN=C1c2ccccc2Cc2ccccc21</smiles>

28<smiles>[R]c1ccc(-c2nn(-c3ccc([N+](=O)[O-])cc3)cc2C2SC(N([R2])C(C)=O)=NN2C(C)=O)cc1</smiles>

27<smiles>CC(=O)NC1=NN(C(C)=O)C2(S1)c1ccccc1Cc1ccccc12</smiles>

29 


\section{Other acyl derivatives}

The intramoleculer cyclization of hydrazide hydrazones have also been carried out with propionic anhydride $\mathbf{3 1}$ (40), benzoyl chloride 32 (48), 33 (63) and substituted isocyanates 35, 36 (71, 72).<smiles>CC(C)=NNC(=O)c1ccncc1</smiles>

30<smiles>O=C(c1ccccc1)N1N=C(c2ccccc2)OC1(c1ccccc1)c1ccccc1</smiles>

32<smiles>CCC(=O)N1N=C(c2ccncc2)OC1(C)C</smiles>

31<smiles>[Y10]C1=NN(C(=O)NC(=O)c2ccc([R])cc2)C(CCCC)(CCCC)O1</smiles> 
The isomer compounds 38 and 39 were synthesized with the different method by Tsoleridis and co-workers (73).<smiles>CC1=NN(C(=O)c2ccccc2)[C@@H]2CCC[C@H]12</smiles>

37

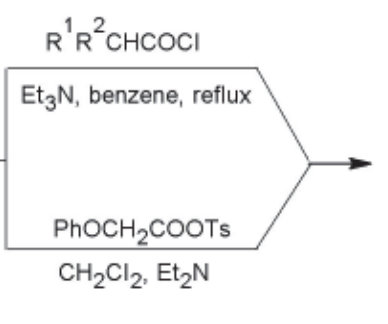

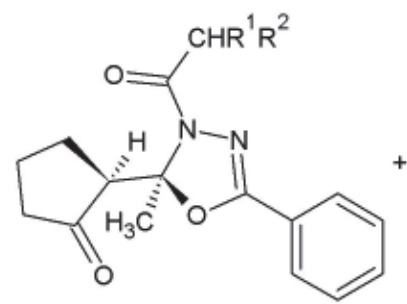

38<smiles>[R2]C(=O)N1N=C(c2ccccc2)O[C@]1(C)[C@H]1CCCC1=O</smiles>

39

\begin{tabular}{|l|l|l|}
\hline & $\mathbf{R}^{\mathbf{1}}$ & $\mathbf{R}^{\mathbf{2}}$ \\
\hline 38a, 39a: & $\mathrm{Cl}$ & $\mathrm{Cl}$ \\
\hline 38b, 39b: & $\mathrm{Cl}$ & $\mathrm{H}$ \\
\hline
\end{tabular}

Desai and co-workers (74) synthesized 3-(substituted-phenylpropenoil)-1,3,4-oxadiazoline derivatives 41 from 3-acetyl-2-(2-chloroquinolin-3-yl)-5-(4-nitrophenyl)-1,3,4-oxadiazoline 40.<smiles>[R]O[N+](=O)c1ccc(C2=NN(C(C)=O)C(c3cc4ccccc4nc3Cl)O2)cc1</smiles>

40<smiles>[R]Cc1ccccc1/C=C/C(=O)N1N=C(c2ccc([N+](=O)[O-])cc2)OC1c1cc2ccccc2nc1Cl</smiles>

41

\section{Different methods for the synthesis of 1,3,4-oxadiazolines}

The regioselective cyclization of 1,4-disubstituted thiosemicarbazides has been shown to be a good method for the synthesis of substituted 1,2,4-triazoles $(75,76)$ and 1,3,4-thiadiazoles $(77,78)$ in alkaline and acidic media respectively. Feng and co-workers (79) published the first report on the regioselective cyclization of 1,3,4-oxadiazolines from 1,4-disubstituted thiosemicarbazides using silver nitrate as an oxidant. The products have isolated as the trans-isomer.<smiles></smiles>

42

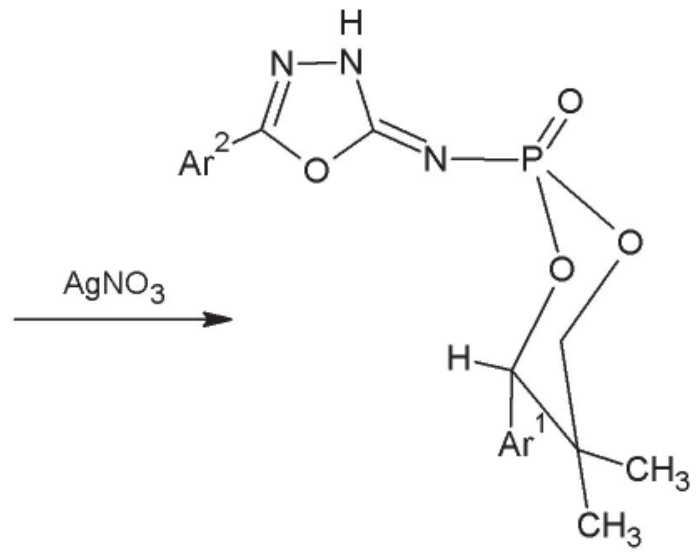

43 
El-Saidi and co-workers (80) prepared the $\Delta^{3}$-1,3,4-oxadizoline derivatives 45 by oxidative cylization of compound 44 using the different starting compound with lead tetraacetate in alcohol.<smiles>[R]OC1(OC)N=NC(C)(C)O1</smiles>

44

45

Also, El-Kaim and co-workers (81) synthesized the $\Delta^{3}-1,3,4-$ oxadiazolines 47 from trichloroacetic acid hydrazones 46 .<smiles>[R]/C=N\NC(=O)C(C)(C)C</smiles>
46

47

\section{Biological Activity}

The investigation of the biological activities of 3-acyl-2,3-dihydro-1,3,4-oxadiazole derivatives has been focused on antibacterial, antitumor, antioxidant, monoamine oxidase inhibitory and anticonvulsant activity.

Rollas and co-workers (45) synthesized 4-fluorobenzoic acid[(4-nitrophenyl/5-nitro-2-furanyl)methylene]hydrazide derivatives and tested against various bacteria and fungus. Compound 48 showed equal activity with ceftriaxone against S.aureus.<smiles>CC(=O)N1N=C(c2ccc(F)cc2)OC1c1ccc([N+](=O)[O-])o1</smiles>

Also, Fuloria and co-workers (82) screened the compounds 49a-e for their antibacterial and antifungal activity against $S$. aureus, $P$. aeruginosa, C. albicans and A. flavus. Compounds were found to be active against tested microorganism.<smiles>[R2]c1ccc(C2OC(CCc3ccccc3)=NN2C(C)=O)c([R])c1</smiles>

49

\begin{tabular}{|c|c|c|}
\hline$a$ & $R_{1}: H$ & $R_{2}:\left(\mathrm{CH}_{3}\right)_{2}$ \\
\hline$b$ & $R_{1}: H$ & $R_{2}: C l$ \\
\hline$c$ & $R_{1}: O H$ & $R_{2}: O H$ \\
\hline$d$ & $R_{1}: H$ & $R_{2}: H$ \\
\hline$e$ & $R_{1}: H$ & $R_{2}: O H$ \\
\hline
\end{tabular}

$50 \mathrm{a}$ and $50 \mathrm{~b}$ were tested for their antitubercular activity against M. tuberculosis H37Rv strain. Compounds showed moderate activity (MIC: 31.25, Isoniazid: $0.25 \mu \mathrm{g} / \mathrm{mL}$ ) (83).

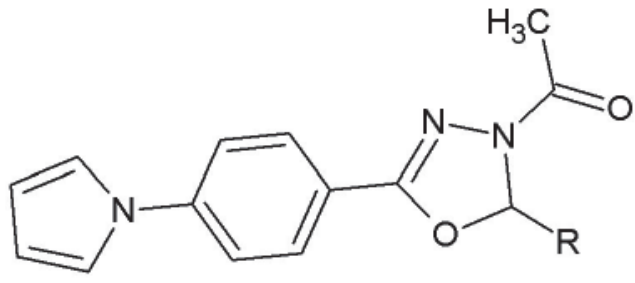

50

\begin{tabular}{|c|c|c|}
\hline$R:$ & $a$ & $-\mathrm{C}_{6} \mathrm{H}_{5}$ \\
\hline & $b$ & $2,6-\mathrm{Cl}_{2} \mathrm{C}_{6} \mathrm{H}_{3}$ \\
\hline
\end{tabular}

The cylization of the pyridoxalisonicotinoyl hydrazone with acetic anhydride gave 51. Compound $\mathbf{5 1}$ exhibited inhibitory activity against $M$. tuberculosis H37Rv (MIC, $6.09 \mu \mathrm{M})(84)$.<smiles>CC(=O)N1N=C(c2ccncc2)OC1c1c(CO)cnc(C)c1O</smiles> 
Chawla and co-workers (85) synthesized a series of 3-acetyl-5(3-chloro-1-benzo[b]thiophen-2-yl)-2-substitutedphenyl-2,3dihydro-1,3,4-oxadiazoles. Among the tested compounds 52a and $52 b$ were found to be most active compounds compare to standart drug ciprofloxacin against $S$. aureus and B. subtilis.

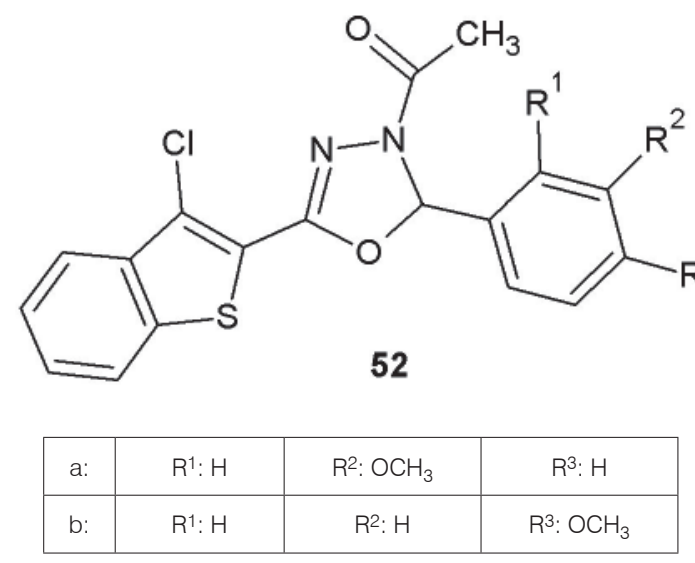

Yang and co-workers (86) synthesized 3-(substituted)aryl-4(acetyl-2-aroyloxymethylene-1,3,4-oxadiazoline-5-yl)-1-phenyl-2-pyrazoline derivatives 53. Their antibacterial activities were found higher than the initial hydrazide-hydrazones against tested microorganisms.<smiles>[R]c1ccc(OCC2OC(c3cn(-c4ccccc4)nc3-c3ccc([R])cc3)=NN2C(C)=O)cc1</smiles>

In a recent publication, Hamdi and co-workers (87) have investigated 1,3,4-oxadiazoline derivatives for their antibacterial and antioxidant activities.

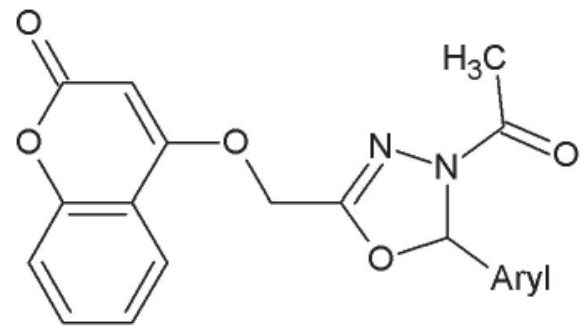

54

\begin{tabular}{l|l|l|l|l|l} 
Aryl: & $-\mathrm{C}_{6} \mathrm{H}_{5^{-}}$ & $4-\mathrm{FC}_{6} \mathrm{H}_{4^{-}}$ & $4-\mathrm{OCH}_{3} \mathrm{C}_{6} \mathrm{H}_{4^{-}}$ & $4-\mathrm{NO}_{2} \mathrm{C}_{6} \mathrm{H}_{4^{-}}$ & 3,4,5- $\left(\mathrm{OCH}_{3}\right)_{3} \mathrm{C}_{6} \mathrm{H}_{2^{-}}$ \\
\hline
\end{tabular}
Generally, the antibacterial activities of 1,3,4-oxadiazoline derivatives screened against $S$. aureus. Indeed, all of the researchs showed that 1,3,4-oxadiazolines were active compounds.

Also, Ishii and co-workers (88) synthesized the 1,3,4-oxadiazolines and tested for their antimicrobial activities against various strains. The most active compounds were 55a-c. Compound 55b showed good activity against $S$. aureus (MIC=1.95-1.25 $\mu \mathrm{g} / \mathrm{mL}$ ) and 55a against $C$. albicans (MIC=3.28-2.62 $\mu \mathrm{g} / \mathrm{mL}$ ).<smiles>[R]c1ccc(C2=NN(C(C)=O)C(c3ccc([N+](=O)[O-])s3)O2)cc1</smiles>

55

\begin{tabular}{|l|c|l|}
\hline & $a$ & $-\mathrm{CF}_{3}$ \\
\hline$R:$ & $b$ & $-\mathrm{OC}_{4} \mathrm{H}_{9}$ \\
\hline & $c$ & $-\mathrm{OCOCH}_{3}$ \\
\hline
\end{tabular}

Omar M. Ali and co-workers (89) synthesized 1,3,4-oxadiazoline derivatives 56 from sugar uracil-1-ylmethylhydrazones by heating in acetic anhydride. Compounds were tested for antiviral activity against hepatitis B virus and showed moderate viral replication inhibition.<smiles>[R2]C1([2H])OC(Cn2cc([Hg])c(=O)[nH]c2=O)=NN1C(C)=O</smiles>

56

Compounds 57a-c were tested for antimicrobial activities various strains. The compounds did not show remarkable activity (90).<smiles>[R]c1ccc(-c2cc(C3OC(C4C5CC6CC(C5)CC4C6)=NN3C(C)=O)no2)cc1</smiles> 
Manojkumar and co-workers (91) prepared 3-acetyl-1,3,4-oxadiazolines 58a-c using starting material 4-methoxycoumarinyl-7oxyacetic acid hydrazide hydrazones.<smiles>[R]c1ccc(C2OC(COc3ccc4oc(=O)cc(C)c4c3)=NN2C(C)=O)cc1</smiles>

58

\begin{tabular}{|c|c|c|}
\hline & $a$ & $\mathrm{CH}_{3}$ \\
\hline $\mathrm{R}:$ & $\mathrm{b}$ & $\mathrm{H}$ \\
\hline & $\mathrm{c}$ & $\mathrm{F}$ \\
\hline
\end{tabular}

The compounds 58a-c have tested for their in vitro cytotoxic activity against DLH and EAC cells. 5-Fluorouracil was used as standart cytotoxic agent. In addition, their antioxidant activities have studied by diphenylpicryl hydrazyl (DPPH) assay method.

Also Jin and co-workers (92) reported that compound 59 was active against PC 3 cells in vitro by MTT method at $0.3 \mu$ M.

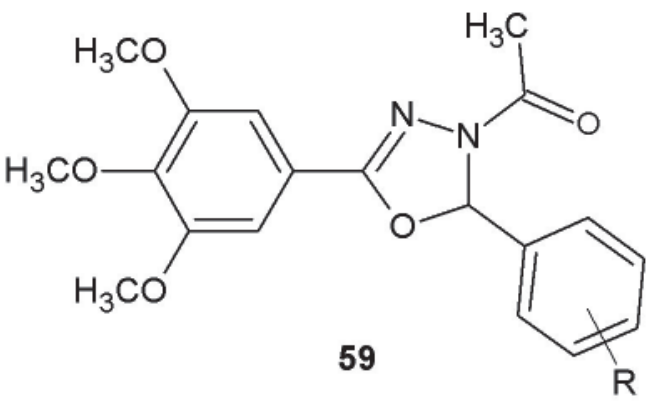

Lee and co-workers (93) prepared 2,5-diaryl-1,3,4-oxadiazoline analogs 59 of combretastatin A4 and tested antiproliferative activities against multiple cancer cell lines and reported that it was the major efficient antioxidant bearing 3,4,5-trimethoxysubstituent in the phenyl ring. Other compounds have also exhibited higher antioxidant activity than Trolox.

Ke and co-workers (72) designed and synthesized a series of oxadiazoline derivatives. All synthesized compounds have inhibited chitin biosynthesis in yeast. Compounds 60 and $\mathbf{6 1}$ have showed the highest inhibitory activity at lower concentrations.<smiles>CCCCC1(CCCC)OC(c2ccccc2Cl)=NN1C(C)=O</smiles>

60<smiles>CCCCC1(CCCC)OC(c2ccc(Cl)cc2Cl)=NN1C(=O)NC(=O)c1ccccc1Cl</smiles>

61 
In 2005, Chimenti and co-workers (94) reported the synthesis of 1-acetyl-3,5-diaryl-4,5-dihydro- $(1 H)$-pyrazole derivatives and their human monoamine oxidase activity against (MAO) $\mathrm{A}$ and $\mathrm{B}$ isoforms.

Recently, Maccioni and co-workers (47) designed and synthesized 3-acetyl-2,5-diaryl-2,3-dihydro-1,3,4-oxadiazole derivatives as isosteres of 1-acetyl-3,5-diaryl-4,5-dihydro-(1H)-pyrazoles to investigate for their inhibitors activity against MAO-A and MAO-B. Some of the compounds 62 exhibited inhibitory activities against the $B$ isoform of the enzyme at nanomolar values. The authors isolated $R$ and $S$ enantiomers of $62 b$ and 62c. The $\mathrm{R}$ enantiomers were found more active than the racemic mixture. These lead compounds may be used for the design of MAO-B selective inhibitors.

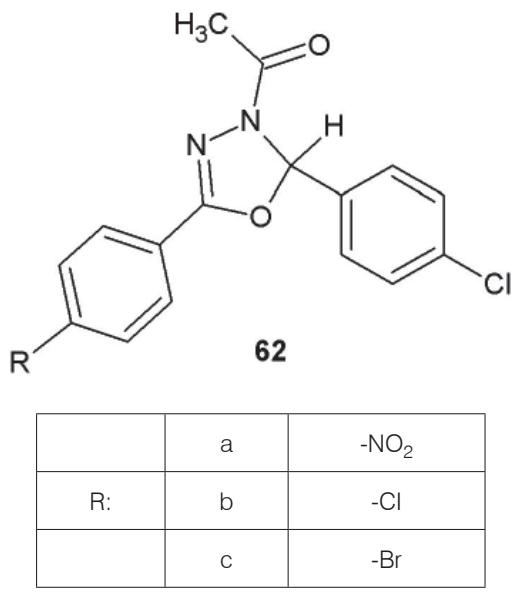

The hydrazones derivatived 3-hydroxy-2-naphthoic acid hydrazide gave compounds 63 . Their anticonvulsant activity were investigated against pentylenetetrazole (PTZ) induced convulsions in mice by Doğan and co-workers (95).<smiles>CC(=O)Oc1cc2ccccc2cc1C1=NN(C(C)=O)C(C)(Cc2ccccc2)O1</smiles>

63

The protection of these compounds was ranged from 0 to $60 \%$. Further research was made on the compound 64 by Şener and co-workers (96).<smiles>COc1cc2ccccc2cc1C1=NN(C(C)=O)C(c2ccccc2)O1</smiles>

The antioxidant effect of compound 64 was tested in mice brain and liver, compared the antioxidant and anticonvulsive effect with that of valproat (VPA), an antiepileptic drug. Compound 64 and VPA significantly decreased lipid peroxidation levels in brain and liver which were elevated after PTZ administration. Compound 64 and VPA showed a protection on brain and liver tissue against oxidative damage seen at during the seizures.

On the other hand, nonsubstituted analogs of 63, 64 were evaluated for biological activities as tubulin polymerization inhibitors by $\mathrm{Hu}$ and co-workers (97).<smiles>CC(=O)N1N=C(c2ccc3ccccc3c2)OC1c1ccc2ccccc2c1</smiles>

Among these compounds 65 showed the most potent antiproliferative activitiy against HepG2, MFC-7 and B16-F10 cells. Docking simulation study revealed that compounds bearing the naphthyl moiety are promising tubulin inhibitors.<smiles>CC(=O)N1N=C(c2ccc(F)cc2)OC1(C)CC(C)(C)C</smiles>

\begin{tabular}{|l|l|l|l}
\hline Aryl: & $4-\mathrm{OH}-\mathrm{C}_{6} \mathrm{H}_{4^{-}}$ & $3-\mathrm{OH}-4-\mathrm{OCH}_{3}-\mathrm{C}_{6} \mathrm{H}_{4^{-}}$ & Furan-2-yl
\end{tabular}

The 3-acetyl-2,5-disubstituted-2,3-dihydro-1,3,4-oxadiazoles were prepared from aryl substituted hydrazones of 4-fluoro benzoic acid hydrazide by Koçyiğit-Kaymakçığlu and coworkers (98). 66 can be interesting source for lead compounds for anti-inflammatory research.

\section{CONCLUSION}

The number of publications on the 3-acyl-2,3-dihydro-1,3,4oxadiazole derivatives have increased in the recent years. There are several reports about the synthesis and biological activity of 3-acyl-2,3-dihydro-1,3,4-oxadiazoles. In this manuscript the related articles of 1,3,4-oxadiazolines are reviewed. The future researches may be focused on the 1,3,4-oxadiazolines for the synthesis of active new drugs. 


\section{REFERENCES}

1. Kitaev YP, Buzykin BI. The Reactions of Hydrazones. Russian Chem Rev 1972;41: 495-515.

2. Rollas S. Synthesis and Spectrometric Analysis of Some Hydrazide Hydrazones I. J Fac Pharm Ist 1981; 17: 41-50.

3. Rollas $S$, Büyüktimkin $S$, Büyüktimkin N, Ülgen M. Yemeni E. Evaluation of some arylhydrazones of N 2-arylidenebenzylic acid hydrazide as antimicroial agents. Pharmazie 1988; 43: 511.

4. Koçyiğit-Kaymakçıŏlu B, Oruç E, Unsalan S, Kandemirli F, Shvets N, Rollas S, Anatholy D. Synthesis and characterization of novel hydrazide-hydrazones and the study their structure-antituberculosis activity. Eur J Med Chem 2006; 41: 1253-61.

5. Rollas S, Küçükgüzel ŞG. Biological activities of hydrazone derivatives. Molecules 2007; 12: 1910-39.

6. Ergenç N, Günay NS. Synthesis and antidepressant evaluation of new 3-phenyl-5-sulfonamidoindole derivatives. Eur J Med Chem 1993; 33: 143-8.

7. Ling A, Plewe M, Gonzalez J, Madsen P, Sams CK, Lau J, Gregor V, Murphy D, Teston K, Kuki A, Shi S, Truesdale L, Kiel D, May J, Lakis J, Anderes K, Iatsimirskaia E, Sidelmann UG, LB Knudsen, Brand CL, Polinsky A. Human glucagon receptor antagonists based on alkylidene hydrazides. Bioorg Med Chem Lett 2002; 12: 663-6.

8. Perdicchia D, Licandro E, Maiorana S, Baldoli C, Giannini C. A new 'one-pot' synthesis of hydrazides by reduction of hydrazones. Tetrahedron 2003; 59: 7733-42.

9. Elassar A-ZH, Dib HH, Al-Awadi NA, Elnagdi MH. Chemistry of carbofunctionally substituted hydrazones. Arkivoc 2007; (ii): 272-315.

10. Belskaya NP, Dehaen W, Bakulev VA. Synthesis and properties of hydrazones bearing amide, thioamide and amidine functions. Arkivoc 2010; (i): 275-332.

11. Richardson DR, Milnes $K$. The potential of iron chelators of the pyridoxal isonicotinoyl hydrazone class as effective antiproliferative agents II: The mechanism of action of ligands derived from salicylaldehyde benzoyl hydrazone and 2-hydroxy-1-naphthylaldehyde benzoyl hydrazone. Blood 1997; 89: 3025-38.

12. Khattab SN. Synthesis and biological activity of novel amino acid-(N'-benzoyl)hydrazide and amino acid- $\left(\mathrm{N}^{\prime}-\right.$ nicotinoyl)hydrazide derivatives. Molecules 2005; 10: 1218-28.

13. Johnson DK, Murphy TB, Rose NJ. Cytotoxic chelators and chelates 1 . Inhibition of DNA synthesis in cultured rodent and human cells by aroylhydrazones and by a copper (II) complex of salicylaldehyde benzoyl hydrazone. Inorg Chim Acta 1982; 67: 159-165.
14. Richardson DR, Ponka P. Pyridoxal isonicotinoyl hydrazone and its analogs: Potential orally effective ironchelating agents fort the treatment of iron overload disease. J Lab Clin Med 1998; 131: 307-15.

15. Mohareb RM, Fleita DH, Sakka OK. Novel synthesis of hydrazide-hydrazones derivatives and their utilization in the synthesis of coumarin, pyridine, thiazole and thiophene derivatives with antitumor activity. Molecules 2011; 16: 16-27.

16. Cui Z, Li Y, Ling Y, Huang J, Cui J, Wang R, Yang X. New class of potent antitumor acylhydrazone derivatives containing furan. Eur J Med Chem 2010; 45: 5576-84.

17. Ajani OO, Obafemi CA, Nwinyi OC, Akinpelu DA. Microwave assisted synthesis and antimicrobial activity of 2-quinoxalinone-3-hydrazone derivatives. Bioorg Med Chem 2010; 18: 214-21.

18. Narasimhan $B$, Kumar $P$, Sharma D. Biological activities of hydrazide derivatives in the new millennium. Acta Pharma Sci 2010; 52: 169-180.

19. Uppal G, Bala S, Kamboj S, Saini M. Therapeutic Review Exploring Antimicrobial potential of hydrazones as promising lead. der pharma chem 2011; 3: 250-68.

20. Küçükgüzel ŞG, Mazi A, Şahin F, Öztürk S, Stables JP. Synthesis and biological activities of diflunisal hydrazide-hydrazones. Eur J Med Chem 2003; 38: 1005-13.

21. Özdemir A, Kaplancıklı ZA, Turan-Zitouni G, Revial G. Synthesis of some novel hydrazone derivatives and evaluation of their antituberculosis activity. Marmara Pharm J 2010; 14:79-83.

22. Gülerman NN, Oruç EE, Kartal F, Rollas S. In vivo metabolism of 4-fluorobenzoic acid [(5-nitro-2-furanyl) methylene] hydrazide in rats. Eur J Drug Metab Pharmacokinet 2000; 25: 103-8.

23. Kömürcü ŞG, Rollas $S$, Ülgen $M$, Gorrod JW, Çevikbaş A. Evaluation of some arylhydrazones of p-aminobenzoic acid hydrazide as antimicrobial agents and their in vitro hepatic microsomal metabolism. Boll Chim Farmaceutico-Anno 1995; 134: 281-5.

24. Imramovsky' A, Polanc $S$, Vinšová J, Kočevar M, Jampílek J, Zuzana Rečková, Kaustová J. A new modification of anti-tubercular active molecules. Bioorg Med Chem 2007; 15: 2551-59.

25. Rollas S. Preclinical Development Handbook: ADME and Biopharmaceutical Properties Editors: Shayne Cox Gad, John Wiley \& Sons, Inc. New Jersey 2008, pp. 829-851.

26. Rollas $S$, Kucukguzel ŞG. Hydrazone, amide, carbamate, macromolecular and other prodrugs of Doxorubicin. Open Drug Deliv J 2008; 2: 77-85. 
27. Bildstein 1, Dubernet C, Couvreur P. Prodrug-based intracellular delivery of anticancer agents. Adv Drug Deliv Rev 2011; 63: 2-23.

28. Rawat J, Jain PK, Ravichandran V, Agrawal RK. Synthesis and evaluation of mutual prodrugs of isoniazid, pamino salicylic acid and ethambutol. Arkivoc 2007; (i): 105-118.

29. Kratz F. DOXO-EMCH (INNO-206): the first albuminbinding prodrug of doxorubicin to enter clinical trials. Expert Opin Investig Drugs 2007; 16: 855-66.

30. Ducry L, Stump B. Antibody-Drug Conjugates: Linking Cytotoxic Payloads to Monoclonal Antibodies. Bioconjugate Chem 2010; 21: 5-13.

31. Küçükgüzel ŞG, Oruç EE, Rollas S, Şahin F, Özbek A. Synthesis, characterization and biological activity of novel 4-thiazolidino 1,3,4-oxadiazoles and some related compounds. Eur J Med Chem 2002; 37: 197-206.

32. Cesur N, Cesur Z, Ergenç N, Uzun M, Kiraz M, Kasimoglu Ö, Kaya D. Synthesis and antifungal activity of some 2-aryl-3-substituted 4-thiazolidinones. Arch Pharm (Weinheim) 1994; 327: 271-72.

33. Kalsi R, Shrimali M, Bhalla TN, Barthwal JP. Synthesis and anti-inflammatory activity of indolyl azetidinones. Indian J Pharm Sci 2006; 41: 353-59.

34. Kumar D, Bux FB, Singh Arun. Synthesis and biological activity of azetidinone. Rasāyan J Chem 2010; 3: 497-502.

35. Mansour AK, Eid MM, Khalil NSAM. Synthesis and reactions of some new heterocyclic carbohydrazides and related compounds as potantial anticancer agents. Molecules 2003; 8: 744-55.

36. Dobrotă C, Paraschivescu CC, Dumitru I, Matache M, Baciu I, Rută LL. Convenient preparation of unsymmetrical 2,5-disubstituted 1,3,4-oxadiazoles promoted by Dess-Martin reagent. Tetrahedron Lett 2009; 50: 1886-88.

37. Safieh KAA, Al-Titi AMS, Zahra JA, Ayoub MT. Oxidative cyclization of arylidene carboxyhydrazides: Synthesis of substituted hydroxydiphenylmethyl-1,3,4-oxadiazoles. JJC 2007; 2: 211-8.

38. Kovařiková $P$, Mokry $M$, Klimeš J, Vávrová K. HPLC study on stability of pyridoxal isonicotinoyl hydrazone. J Pharmaceut Biomed Anal 2006; 40: 105-112.

39. Ülgen $M$, Barlas-Durgun $B$, Rollas $S$, Gorrod JW. The in-vitro hepatic microsomal metabolism of benzoic acid benzylidene hydrazide. Drug Metabol Drug Interact 1997; 13: 285-94.

40. Hearn MJ, Chanyaputhipong PY. Preparation and spectroscopic properties of 3-acyl-1,3,4-oxadiazolines. J Heterocyclic Chem 1995; 32: 1647-49.

41. Yale HL, Losee K, Martins J, Holsing M, Perry FM, Bernstein J. Chemotherapy of experimental tuberculosis. VIII. The synthesis of acid hydrazides, their derivatives and related compounds. J Am Chem Soc 1953; 75: 1933-42.

42. Somogyi László. Structure and reactions of aldose semicarbazone and thiosemicarbazone derivatives under acetylating conditions. Carbohydr Res 1979; 75: 325-30.

43. Hassan E, Al-Ashmawi MI, Abdel-Fattah B. Synthesis and antimicrobial testing of certain oxadiazoline and triazole derivatives. Pharmazie 1983; 38: 833-5.

44. Ergenç N, Rollas $S$, Topaloğlu Y, Ötük G. Synthesis and characterization of new 1,3,4-oxadiazolines. Arch Pharm 1989; 322: 837-8.
45. Rollas S, Gülerman NN, Erdeniz H. Synthesis and antimicrobial activity of some new hydrazones of 4-fluorobenzoic acid hydrazide and 3-acetyl-2,5-disubstituted1,3,4-oxadiazolines. Farmaco 2002; 57: 171-4.

46. Rahman MMA, EL Ashry ESH, Abdallah AA, Rashed N.C-(Polyacetoxy)alkyloxadiazolines and related compounds. Carbohydr Res 1979; 73: 103-11.

47. Maccioni E, Alcaro S, Cirilli R, Vigo S, Cardia MC, Sanna ML, Meleddu R, Yanez M, Costa G, Casu L, Matyus P, Distinto S. 3-Acetyl-2,5-diaryl-2,3-dihydro-1,3,4-oxadiazoles: A new scaffold for the selective inhibition of Monaamine Oxidase B. J Med Chem 2011; 54: 6394-98.

48. Somogyi L. Notes on the reactions of ketone acylhydrazones under acylation conditions. Tetrahedron 1985; 41: 5187-90.

49. Somogyi L. Stereochemical aspects of the formation of diastereo isomeric 3-acetyl-2-(polyacetoxyalkyl)-5-phenyl-2,3-dihydro-1,3,4-oxadiazoles. Carbohydr Res 1988; 182: 19-29.

50. Somogyi L, Czugler $M$, Sohár P. Synthesis and stereostructure of some 5,5' -disübstituted-3-acetyl-2,2'-bi-2H1,3,4-oxa(thia)diazolines. Tetrahedron 1992; 48: 9355-62.

51. Somogyi L. Synthesis, oxidation and dehydrogenation of cyclic N,O- and N,S- acetals. Part III. [1,2] Transformation of N, O-acetals: 3-Acyl-1,3,4-oxadiazolines. J Heterocyclic Chem 2007; 44: 1235-46.

52. Durgun B, Çapan G, Ergen N, Rollas S. Synthesis characterization and biological evaluation of new benzylidenebenzohydrazides and 2, 5-disubstituted-2,3-dihydro-1,3,4-oxadiazolines. Pharmazie 1993; 48: 942-3.

53. Büyüktimkin $S$, Rollas $S$, Ülgen $M$, Ötük G. Some 1,3,4-oxadiazoline derivatives prepared by starting form benzylic acid hydrazide arylhdrazones and their antimicrobial evaluation. Pharmazie 1990; 45: 865.

54. Fathy NM, Abdel-Motti F, Abdel-Megeid FME. Synthesis of some thienoquinoline derivatives with expected pharmacological activity. Com Fac Sci Univ Ank 1991; 37: 1-8.

55. Khalil MA, El-Sayed OA, El-Shamy HA. Synthesis and antimicrobial evaluation of novel oxa(thia)diazolylquinolines and oxa(thia)diazepino[7,6-b]quinolines. Arch Pharm (Weinheim), 1993; 326: 489-92.

56. Farghaly AAH. Synthesis, reactions and antimicrobial activity of some new indolyl-1,3,4-oxadiazole, triazole and pyrazole derivatives. J Chin Chem Soc 2004; 51: $147-$ 56.

57. Mogilaiah K, Kumara Swamy $T$, Vinay Chandra A, Srivani N. Microwave assisted synthesis of 1,3,4-oxadiazolyl 1,8-naphthyridines under solvent-free conditions using solid support. Indian J Chem 2009; 48(B): 1462-65.

58. Dewangan D, Pandey A, Sivakumar T, Rajavel R, Dubey RD. Synthesis of some novel 2,5-disubstituted 1,3,4-oxadiazole and its analgesic, anti-inflammatory, anti-bacterial and anti-tubercular activity. Int J Chem Tech Res 2010; 2: 1397-412.

59. Burch HA. Nitrofuryl Heterocycles. V. 4-Acyl-5,5-dialkyl-2-(5-nitro-2-furyl)-D2-1,3,4-oxadiazolines. J Med Chem1967; 10: 91-3. 
60. Cerioni G, Maccioni E, Cardia MC, Vigo S, Mocci F. Characterization of 2,5-diaryl-1,3,4-oxadiazolines by multinuclear magnetic resonance and density functional theory calculations. Investigation on a case of very remote Hammett correlation. Magn Reson Chem 2009; 47: 727-33.

61. Osório TM, Monache FD, Chiaradia LD, Mascarello A, Stumpf TR, Zanetti CR, Silveira DB, Barardi CRM, Smânia EFA, Viancelli A, Garcia LAT, Yunes RA, Nunes RJ, Smânia A. Antibacterial activity of chalcones, hydrazones and oxadiazoles against methicillin-resistant Staphylococcus aureus. Bioorg Med Chem Lett 2012, 22: 225-30.

62. Eid AI, Ragab FA, El-Ansary SL, El-Gazayerly SM, Mourad FE. Synthesis of new 7-substituted 4-methylcoumarin derivatives of antimicrobial activity. Arch Pharm (Weinheim)1994; 327: 211-3.

63. Armesto D, Gallego MG, Horspool WM, Ramos A. Unexpected reactivity of the anion derived from benzophenone benzoylhydrazone in the presence of electrophiles. Tetrahedron Lett 1988; 29: 3581-4.

64. Bacu E, Couture A, Grandclaudon P. Synthesis and characterization of 2,2-disubstituted-5-(2-phenothiazin-10ylethyl)-2,3-dihydro-1,3,4-oxadiazoles. Synth Commun 2003; 33: 143-151.

65. Islam R, Mohsin M. Synthesis of isatin, 5-chloroisatin and their D2-1,3,4-oxadiazoline derivatives for comparative study on brine shrimp. Bangladesh J Pharmacol 2007; 2: 7-12.

66. Han D, Meng XB, Wang LN, Liu H, Yao Y, Wang Z, Yang ZJ, Liu ZM, Li ZJ. Efficient synthesis of a series of novel fructose-based 3-acetyl-5-alkyl-2,3-dihydro-1,3,4-oxadiazole derivatives and studies of the reaction mechanism. Tetrahedron: Asymmetry 2009; 20: 399-410.

67. Wang LN, Han D, Xu FF, Meng XB, Li ZJ. Microwaveassisted efficient synthesis of glucose-based 3-acetyl-5alkyl-2,3-dihydro-1,3,4-oxadiazole derivatives catalyzed by sodium acetate. Carbohydr Res 2009; 344: 2113-9.

68. Allam YA, Nawwar GAM . Facile synthesis of 3-spiroindolines. Heteroatom Chemistry 2002; 13: 207-10.

69. Abadi AH, Eissa AAH, Hassan GS. Synthesis of novel 1,3,4-trisubstituted pyrazole derivatives and their evaluation as antitumor and antiangiogenic agents. Chem Pharm Bull 2003; 51: 838-44.

70. Alho MMA, Moglioni AG, Brousse B, Moltrasio GY, D'Accorso NB. Synthesis and characterization of 2,2-disubstituted thiadiazolines. Arkivoc 2000; (iv): 627-40.

71. Ke S, Li Z, Qian X. 1,3,4-Oxadiazoline-3(2H)-carboxamide derivatives as potential novel class monoamine oxidase (MAO) inhibitors: Synthesis, evaluation, and role of urea moiety. Bioorg Med Chem 2008; 16: 7565-72.

72. Ke S, Liu F, Wang N, Yang Q, Qian X. 1,3,4-Oxadiazoline derivatives as novel potential inhibitors targeting chitin biosynthesis: Design, synthesis and biological evaluation. Bioorg Med Chem Lett 2009; 19: 332-5.

73. Tsoleridis CA, Stephanidou-Stephanadou $J$, Gounaridis P, Zika H, Pozarentzi M. Unusual reaction of N-aroyldihydrocyclopenta-pyrazolidinol with ketenes: formation of 1,3,4-oxadiazoles. Tetrahedron 2003; 59: 4591-601.
74. Desai NC, Dodiya AM. Conventional and microwave techniques for synthesis and antimicrobial studies of novel 1-[2-(2-chloro(3-quinolyl))-5-(4-nitrophenyl)(1,3,4-oxadiazolin-3-yl)]-3-(aryl)prop-2-en-1-ones. Med Chem Res 2011; DOI: 10.1007/s00044-011-9670-9.

75. Gülerman N, Rollas S, Kiraz M, Ekinci AC, Vidin A. Evaluation of antimycobacterial and anticonvulsant activities of new 1-(4-fluorobenzoyl)-4- substituted-thiosemicarbazide and 5-(4-fluorophenyl)-4-substituted2,4-dihydro-3H-1,2,4-triazole-3-thione derivatives. Farmaco 1997; 52: 691-5.

76. Shaker RM. The chemistry of mercapto- and thione- substituted 1,2,4-triazoles and their utility in heterocyclic synthesis. Arkivoc 2006; (ix): 59-112.

77. Rollas S, Karakuş S, Barlas-Durgun B, Erdeniz H, Kiraz M. Synthesis and antimicrobial activity of some 1,4-disubstituted thiosemicarbazide and 2,5- disubstituted 1,3,4-thiadiazole derivatives. Farmaco 1996; 51: 811-4.

78. Oruç EE, Rollas S, Kandemirli F, Shvets N, Dimoglo A. 1,3,4-Thiadiazole derivatives. Synthesis, structure elucidation, and structure-antituberculosis activity relation investigation. J Med Chem 2004; 47: 6760-67.

79. Feng D, Huang $Y$, Chen $R, Y u Y$, Song $H$. A novel of 2,5-disubstituted 1,3,4-oxadiazolines by the regioselective cyclization of 1,4-disubstituted thiosemicarbazides. Synthesis 2007; 12: 1779-84. $80 . \quad$ El-Saidi M, Kassam K, Pole DL, Tadey T, Warkentin J. 2,2-Dialkoxy-D31,3,4-oxadiazolines: Convenient Thermal Sources of Dialkoxycarbenes. J Am Soc 1992; 114: 8751-2.

81. El Kaim L, Le Menestrel I, Morgentin R. Trichloroacetic acid hydrazones I: New formation of 1,3,4-oxadiazoles from aldehydes. Tetrahedron Lett 1998; 39: 6885-8.

82. Fuloria $N K$, Singh $V$, Shaharyar $M$, Ali M. Synthesis and antimicrobial evaluation of some new oxadiazoles derived from phenylpropionohydrazides. Molecules 2009; 14: 1898-903.

83. Joshi SD, Vagdevi HM, Vaidya VP, Gadaginamath GS. Synthesis of new 4-pyrrol-1-yl benzoic acid hydrazide analogs and some derived oxadiazole, triazole and pyrrole ring systems: A novel class of potential antibacterial and antitubercular agents. Eur J Med Chem 2008; 43: 1989-996.

84. Baquero E, Quinones $W$, Ribon $W$, Caldas ML, Sarmiento L, Echeverri F. Effect of an oxadiazoline and a lignan on mycolic acid biosynthesis and ultrastructural changes of Mycobacterium tuberculosis. Hindawi Publishing Corporation Tuberculosis Research and Treatment 2011; 1-6.

85. Chawla R, Arora A, Parameswaran MK, Sharma PC, Michael S, Ravi TK. Synthesis of novel 1,3,4-oxadiazole derivatives as potential antimicrobial agents. Acta Pol Pharm 2010; 67: 247-53.

86. Yang JF, Cao H, Liu H, L, BQ, Ma YM. Synthesis and bioactivity of novel bis-heterocyclic compounds containing pyrazole and oxadiazoline. J Chin Chem Soc 2011; 58 : 369-75.

87. Hamdi N, Passarelli V, Romerosa A. Synthesis, spectroscopy and electrochemistry of new 4-(4-acetyl-5-substituted-4,5-1,3,4-oxodiazol-2-yl)methoxy)-2H-chromen-2ones as a novel class of potential antibacterial and antioxidant derivatives. CR Chimie 2011; 14: 548-55. 
88. Ishii M, Jorge SD, de Oliveria AA, Palace-Berl F, Sonehara IY, Pasqualoto KFM, Tavares LC. Synthesis, molecular modeling and preliminary biological evaluation of a set of 3-acetyl-2,5-disubstituted-2,3-dihydro-1,3,4-oxadiazole as potential antibacterial, anti-Trypanosoma cruzi and antifungal agents. Bioorg Med Chem 2011; 19: 6292-301.

89. Ali OM, Amer HH, Abdel-Rahman AAH. Synthesis and antiviral valuation of sugar uracil-1-ylmethylhydrazones and their oxadiazoline derivatives. Synthesis 2007; 18: 2823-8.

90. El-Emam AA, Alrashood KA, Al-Omar MA, Al-Tamimi AMS. Synthesis and antimicrobial activity of $\mathrm{N}^{\prime}$-heteroarylidene-1-adamantylcarbohydrazides and ( \pm )-2-(1-adamantyl)4-acetyl-5-[5-(4-substitutedphenyl-3-isoxazoly)]-1,3,4-oxadiazolines. Molecules 2012; 17: 3475-83.

91. Manojkumar P, Kochupappy R, Subbuchettiar G. Synthesis of coumarin heterocyclic derivatives with antioxidant activity anda in vitro cytotoxic activity against tumour cells. Acta Pharm 2009; 59: 159-70.

92. Jin L, Chen J, Song B, Chen Z, Yang S, Li Q, Hu D, $\mathrm{Xu}$ R. Synthesis, structure, and bioactivity of $\mathrm{N}^{\prime}$ substituted benzylidene-3,4,5-trimethoxybenzohydrazide and 3-acetyl-2-substituted phenyl-5-(3,4,5trimethoxyphenyl)-2,3-dihydro-1,3,4-oxadiazole derivatives. Bioorg Med Chem Lett 2006; 16: 5036-40.

93. Lee $L$, Robb LM, Lee $M$, Davis $R$, Mackay $H$, Chavda $S$, Babu B, O’Brien EL, Risinger AL, Mooberry SL, Lee M. Design, synthesis, and biological evaluations of 2,5-diaryl-2,3-dihydro-1,3,4-oxadiazoline analogs of Combretastatin-A4. J Med Chem 2010; 53: 325-34.
94. Chimenti F, Bolasco A, Manna F, Secci D, Chimenti P, Befani O, Turini P, Giovannini V, Mondovi B, Cirilli R, La Torre F. Synthesis and selective inhibitory activity of 1-acetyl-3,5-diphenyl-4,5-dihydro-(1H)-pyrazole derivatives against Monaamine oxidase. J Med Chem 2004; 47: 2071-4.

95. Doğan HN, Rollas $S$, Erdeniz H. Synthesis, structure elucidation and antimicrobial activity of some 3-hydroxy-2naphthoic acid hydrazide dervatives. Farmaco 1998; 53: 462-7.

96. Şener G, Keyer-Uysal M, Doğan HN, Rollas S. 2-(3-Acetyloxy-2-naphthyl)-4-acetyl-5-phenyl-1,3,4-oxadiazoline suppresses pentylenetetrazol-induced convulsive and oxidative activity on mice. Acta Pharm Turcica 2003; 45: 61-7.

97. Hu Y, Lu X, Chen K, Yan R, Li QS, Zhu-HL. Design, synthesis, biological evaluation and molecular modeling of 1,3,4-oxadiazoline analogs of combretastatin-A4 as novel antitubulin agents. Bioorg Med Chem 2012, 20: 903-9.

98. Koçyiğit-Kaymakçığlu $B$, Oruç-Emre EE, Ünsalan $S$, Tabanca N, Khan SI, Wedge DE, İşcan G, Demirci F, Rollas S. Synthesis and biological activity of hydrazidehydrazones and their corresponding 3-acetyl-2,5-disubstituted-2,3-dihydro-1,3,4-oxadiazoles. Med Chem Res 2011; DOI 10.1007/s00044-011-9882-z. 